\title{
Guy Wells
}

\section{Emergence and Evanescence: Republicanism and the Res Publica at Antwerp before the Revolt of the Netherlands*}

One of the joys Antwerp has offered its visitors for over four centuries is the sheer spectacle of its Groote Markt. Now, as in the 1560 's, one can watch a steady confluence and interaction of Antwerpers and travellers passing through a setting dominated by the city's superb town hall. Sitting in that square to enjoy one of the area's incomparable monastery beers gives one the opportunity to contemplate at length the biggest and most conspicuous document Antwerp generated about its political situation in the mid-sixteenth century, namely the town hall itself.

Antwerp's stadbuis was begun in early 1561 . From the beginning, one of its purposes was simply to be something splendid. In one way or another, any such edifice is likely to embody a political statement; Antwerp's spoke on many levels. The very size and magnificence of the building were expressions of a change in the city's sense of identity: it was designed to befit a metropolis, to ratify its importance, to express its pride of place among the great cities of the world. For a structure with such a purpose, we would expect the ceremony at which its first stone was laid to have been carefully arranged to embody and reflect the polity which was raising it up. What we find in accounts of the foundation ritual, however, is striking for its lack of clarity. The so-called first stone was laid by the Margrave and Amman, the local representatives of Philip II. But the Burgomasters of the town also laid their own stone, which the chroniclers called a fundamentsteen, or foundation stone ${ }^{1}$. As an allegory of the original foundation of the city of Antwerp, as a ritual of precedence and authority, the ceremony left the political relationship between the ruler and the city dramatically ambiguous and unclear.

The decoration of the completed building replicates the ambiguity of its foundations. We find Philip's arms emblazoned in the center of the façade, and the eagle at

- I must acknowledge my gratitude to the Cornell Branch of Telluride Association for its hospitality while this paper was in preparation. Heartfelt thanks also to Professor Guy Tops of UFSIA (Antwerp); Scott Swanson and Clive Holmes of Cornell University; and J. Michael Snodgrass of Ohio University for their comments and help. Finally, I am indebted to the staff of Oberlin College Library for their many kindnesses.

1 Anon., Antwerpsch Chronykje ... sedert Den jare 1500 tot het jaer 1574 (Antwerp 1743) 58; Floris Prims, Geschiedenis van Antwerpen (Antwerp 1927-1949) VIII, 1, 25-26. 
the very top may be an emblem of Philip's unique status ${ }^{2}$. But they are parts of a larger scheme of symbols: arrayed on either side are the arms of the duchy of Brabant and the Marquisat of Antwerp, and the eagle itself is framed by obelisks whose pediments are engraved with the letters S.P.Q.A. - Senatus Populusque Antwerpiae. These proud tetragrams sent a definite message to members of the king's circle and court. It was expressed most clearly by the Cardinal Granvelle's provost Morillon a few years later, when he reacted openly to it: "It would be really good to make them shave off their S.P.Q.A. which they inscribe everywhere on their buildings and edifices, claiming a free republic and that the prince can command nothing of them without their consent." ${ }^{3}$ The people who designed the stadbuis must have known that this is how their symbolism would be seen; for them, as for the provost, the building was, if not a fullfledged republican statement, at least an ambiguous one which could be seen to have definite republican overtones.

Another document from the mid-1560's seems to echo the republican tendencies evident in the town hall. This is the lengthy description of Antwerp by Lodovico Guicciardini, the nephew of the great Florentine historian and a longtime resident of the city. He begins his discussion of Antwerp's government with a summary of the relative positions of city and prince:

Antwerp has for its Lord and Prince the Duke of Brabant as Marquis of the Holy Empire: but with so many and great privileges, obtained in ancient times, that she is ruled, maintained, policed and governed by herself, almost like a free city, and a republice and free seigneurie; save, always, with respect to the rights and superiority of the Prince ${ }^{4}$.

Guicciardini conveys no sense of tension or conflict; he describes the city as puuzella, virgin, since it has never rebelled against its prince. Why should it, when it is, in his words, "freed of all subjection"? With Philip off in Spain, the emperor a distant figure, and Antwerp in happy autonomy on the banks of the Schelde, the only real intersection of city and monarch seems to be ceremonial, in the occasional festivals which marked the Joyous Entries, or the meetings of the Order of the Golden Fleece in the city - and even these in Guicciardini come across not so much as demonstrations of the majesty of the central power as ornaments to the city's own greatness.

One other action, which took place while the Town Hall was abuilding and while the Florentine was still planning his work, also strongly suggests the efforts of some high Antwerp officials to affirm the city's direct ties with the Emperor and put legal

${ }^{2}$ Since it lacks a double head, it is difficult to say that the eagle is definitely a Habsburg imperial emblem. Since it is perched on a sphere which suggests imperium over the world, Dr. Fröschl has suggested that it might be an allusion to Philip's claim to precedence as being the son of an Emperor.

3 "Et seroit fort bien de leur faire raser leur S.P.Q.A. qu'ilz intitulent partout en leurs bastiments et edifices, prétendantz républicque libre, et que le prince ne leur peult rien commander sans leur consentement." Morillion to Granvelle, 9 May 1567, in: Edmound Poullet (ed.), Correspondance du Cardinal Granvelle, 1565-1586 (Brussels 1877-1896) II, 426.

4 "Ha primieramente Anuersa per sua signore, \& Principe il Duca di Brabante, come Marchese del sacro Imperio, ma con tanti \& tali preuilegi obtenuti ab antico, che ella come da per se (salve siempre il iure \& superiorità del Principe) quasi a modo di citta libera, \& di Republica si regge \& Si gouerna." Lodovico Guicciardini, Descrittione ... di tutti i paesi bassi (Antwerp 1567) 90.

${ }^{5}$ Ibid., 84, 82. 
emphasis on its parallel, rather than subordinate, hierarchical position in relation to Philip of Spain. This was the Burgomaster van Stralen's project, at the Imperial coronation in Frankfort in 1562, to obtain a confirmation of the city's privileges from the new emperor. As with the imagery in the town hall, tongues wagged in the royal camp at this presumption, and Philip's ambassador in London reported talk among the merchants that Antwerp was planning "to give herself to the empire"6. The article on van Stralen in the old Biograpbie Nationale treats the project as an accomplished fact'.

It is tempting to take these three episodes together and project an emerging republican ideology in Antwerp in the 1560's. They suggest a tantalizing scenario: Antwerp, the center of dynamic merchant capitalism in early sixteenth-century Europe, whose meteoric growth both reflected and generated new social and economic patterns, also strained to break the shackles of the old hierarchy and set itself up as a mercantile republic. For many historians of the nationalist age, they confirmed the city's readiness for the Netherlands republic's coming struggle for independence, and betokened the natural direction in which the city should be drawn.

I think we should reject this temptation. When we look closely at the documentation on van Stralen's trip to Frankfurt, we find that the Burgomaster never got there. The mission was actually quite hastily conceived, and was repudiated by the town council on the urgent advice of its own senior Pensionary - who was normally a canny and aggressive champion of the city's legal immunities ${ }^{8}$. As for Guicciardini: even when the theoretical merit of his formulations is put aside, they have an aura of unreality when viewed in context. His dedicatory Epistle was dated in the fall of 1566 , when Antwerp had been on the edge of rebellion and chaos for months, and had taken on the Prince of Orange as its de facto ruler - whether on behalf of the central government, as the city magistrates claimed, or to work against it, as the Calvinists hoped and the central government later charged. By the time the book was generally available, van Stralen was under arrest for treason and the Duke of Alba's engineers were surveying sites for a citadel in Antwerp whose architectural and military message made all talk of a republic look fanciful indeed. The book might have evoked some nostalgic yearnings from some town councillors, but it cannot have been taken seriously as a description of political realities.

These specifics aside, Guicciardini's formulation ignores a deeper structural alignment which had generated Antwerp's traffic and its greatness'. Antwerp had blossomed precisely because its rulers had formed, over the previous two or three genera-

${ }^{6}$ Aquila to Granvelle, 13 December 1562, in: Kervyn de Lettenbove (ed.), Relations Politiques des Pays-Bas et de l'Angleterre, sous le Règne de Philippe II (Brussels 1882-1900) II, 209-210.

7 Biographie Nationale, Publiée par l'Académie des Sciences des Lettres et des Beaux-Arts de Belgique (Brussels 1866-1970) XXIV, 134.

${ }^{8}$ The mission to Frankfurt is discussed in detail in my unpublished doctoral dissertation, Antwerp and the Government of Philip II, 1555-1567 (Cornell University 1982) 247-249. (Hereafter referred to as Wells, Antwerp).

9 Antwerp's rise to greatness has been the subject of much scholarly and popular writing. A good synthesis is in Leon Voet, De Gouden Eeuw van Antwerpen (Antwerp 1974), or the first chapter of G. D. Ramsay, The City of London in international politics at the accession of Elizabeth Tudor (Manchester 1975). 
tions, a strong working alliance with the Habsburgs. The city waxed with, not in spite of, the world empire which Charles $V$ assembled and passed on. The trading franchises and the great fairs, the opportunities to chase the profits from large-scale government finance - these all had their being and significance within the context of a world-wide empire, of which the city was only a small, albeit possibly integral, part ${ }^{10}$. Many of the large fortunes of the city's patricians - most of whom were not involved in day-to-day business - had their foundations in actions imposed on the city by central government actions and grants. Two examples of this are the spectacular changes in land values and the opportunities for insider trading and graft which arose from the fortification of the city in the 1540 's, or the beer monopoly which was attempted under Gilbert van Schoonbeke's leadership in the mid-1550' $\mathrm{s}^{11}$. These were projects - innovations - of a magnitude which an urban elite alone would have been unable to undertake. Antwerp's magisterial class - many of the very same people who promoted the stadbuis and patronized Guicciardini - undertook these, and tried to enrich themselves, as collaborators with a far greater economic and political power than a city republic could ever hope to be. To be sure, they wrangled with the central government continually over their semi-autonomous jurisdictions and the extent and preservation of their privileges. But these were truly privileges: private laws which had meaning only when the law-giver was also part of the equation. In time of crisis, the very Senatus of the S.P.Q.A. was kept in place, not by its own power or the action of the Populus, but by the armed force of a distant monarch whose backing was essential for the maintenance of the current order of things. If we read Morillon's comments about the town hall in this light, they are not so much a complaint about a republican movement in Antwerp as a mockery of such an idea's utter absurdity.

Nevertheless, having torpedoed the most apparently suggestive bits of evidence of civic republicanism in Antwerp, I would argue that there did indeed exist an unspoken Res Publica there, one whose persistence, if not actual stability over time should qualify it as a sort of presence, a force, albeit one which had no direct institutional manifestation. During the period of Antwerp's rise to greatness, its outlines are everywhere present and evident but never explicit. In order to describe it, it is necessary to define both what the Res involved was, and the nature of the Publicum which sought to foster, preserve, possess, and live within it.

In this period, all cities depended on immigration just to maintain population levels. Antwerp's great expansion means, above all, that a large number of individual people continually decided to move there, and, having done that, from year to year - and sometimes from crisis to crisis - chose to stay there. For someone between about $\mathbf{1 4 9 0}$ and 1565 , who was looking for a place to live and work, to trade and bring up children,

10 This argument is presented at length in Wells, Antwerp, esp. 36-41.

${ }^{11}$ On the latter, see Hugo Soly, De Brouwerijenonderneming van Gilbert van Schoonbeke (15521562) (Ghent 1967). For land speculation, see the same author's Grondspeculatie en Kapitalisme te Antwerpen in de 16de eeuw, in Economisch en Sociaal Tijdschrift XXVII (1973) 291-302, and Fortificaties, belastingen en corruptie te Antwerpen in het midden der 16de eeuw, in: Bijdragen tot de Geschiedenis LIII (1970) 191-210. 


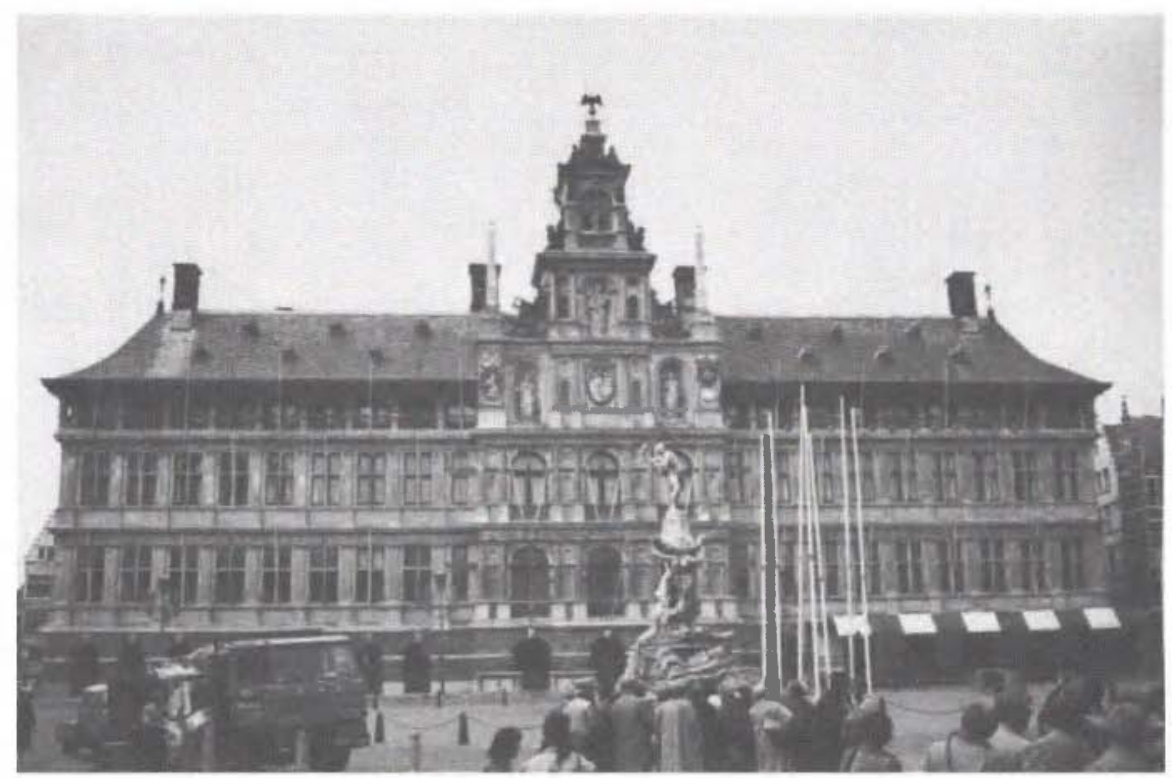

Antwerp's Town Hall

what was the main thing about Antwerp which made it so attractive? Many individual elements contributed to the city's drawing power: the physical environment was relatively benign. The river did not need constant dredging, and provided a safe harbor. There was room and land available to expand, and if one did really well in business, there were readily available "pleasure houses" and even minor seigneuries in the neighbouring countryside. The city was relatively well located in Europe, as it continues to be today; it was not the only good location on Europe's north coast, but it was as serviceable as any other. Militarily, it was in a relatively out-of-the-way place, rarely subject to attack or serious threat. (And note that when one mercenary raider did threaten the city, in 1542, it almost immediately prompted the construction of an extensive, state-of-the-art, fortification system which, not incidentally, encompassed large empty areas for future growth.) The legal environment was equally benign: Antwerp enjoyed the collection of privileges and immunities which all the great Brabant towns had secured in the Joyeuse Entree and maintained over two centuries of constant wrangling with their Dukes. This meant, above all, that the city councils had a monopoly of jurisdiction over criminal cases involving their citizens, who maintained the right to be tried according to local laws in local courts ${ }^{12}$. In addition to the privileges of the other Brabant towns, Antwerp had some specific commercial privileges which made it especially easy to do business there: there were the two great trade fairs

${ }_{12}$ Philip II's Joyeuse Entree is published in Jeanne Mennes, De Staten van Brabant en de Blijde Inkomst van Kroonprins Filips in 1549, in: Standen en Landen XVIII (1959) 49-165. 
around Pentacost and St. Bavo's day, and numerous lesser accommodations with which the Habsburgs had rewarded the city for its support during the wars and rebellions of the late $1480^{\prime} \mathrm{s}^{13}$. The combination of internal legal autonomies and the close relationship with the Habsburgs which the city's burgeoning trade both betokened and reënforced, was particularly attractive. To return to my question, the "main thing" about Antwerp was not any one of its individual attributes or advantages, but their coincidence, their combination, their synergy.

It was this system of conditions which acted as a magnet for enterprising and adventurous immigrants from all over Europe; taken as a whole, it was also the matrix for the Res in a Res Publica which I would say existed in Antwerp. This was not a physical or legal or formally institutional thing; it was an emergent property of a particular combination and balance of visible circumstances and policies ${ }^{14}$. For all its material evanescence, though it was a powerful presence at the heart of the city's practical politics. I would argue that the maintenance of a stasis among the forces which people in Antwerp themselves saw as essential to the city's dynamism was the central object not only of its magistrates' activities throughout the period we are looking at, but also of the so-called popular disturbances which come at its end and midway through it.

The Burgomasters and town council had no explicit legal or institutional connection with the Res Publica whose outlines I propose. They had no particular charge to foster or preserve it. And yet, on another level, many of them were themselves its products. Two of the great Burgomasters of midcentury, Alvaro van Almaras and Antoon van Stralen, were second-generation immigrants to the city, whose families had waxed spectacularly wealthy in commerce. These people's fortunes were bound up with the city's continual ability to attract new people and business. Even if they were no longer directly involved in trade, their banking activities depended on a never-ceasing flow of new money; even the value of their real estate depended on Antwerp's

${ }_{13}$ Wells, Antwerp, 39-41.

${ }^{14}$ My use of the term "emergent property" is suggested by recent discussions of the theory of consciousness, particularly Roger W. Sperry, In Search of Psyche, in: The Neurosciences: Paths of Discovery, ed. by Frederic G. Worden, et al. (Cambridge, Mass. 1975) 425-422; and Consciousness, Freewill and Personal Identity, in Brain Behaviour and Evolution, ed. by David A. Oakly and H.C. Plotkin (London 1979) 219-228. The original concept is found in C. D. Broad, The Mind and its Place in Nature (London 1925) particularly 61-69. Broad's ideas have been the subject of much criticism and debate. Particularly critical views are given in Paul Henle, The Status of Emergence, in: Journal of Philosophy XXXIX (1942) 486-492; Ernest Nagel, The Structure of Science: Problems in the Logic of Scientific Explanation (New York 1960) 366-380; and Gordon G. Brittan, Explanation and Reduction, in: Journal of Philosophy LXVII (1970) 446-457. Broad's concept has been refined in the course of some spirited exchanges, including that between Carl Hempel and Paul Oppenbeim and David Miller in Philosophy of Science XV (1948) 135-175, 348-352; see also Artbur Pap, The Concept of Absolute Emergence, in: British Journal for the Philosophy of Science II (1952) 302-311, and P. E. Meebl and Wilfrid Sellars, The Concept of Emergence, in: Minnesota Studies in the Philosophy of Science, 1 (1956) 239-252. A balanced summary of the debate is T. A. Goudge, Another Look at Emergent Evolutionism, in: Dialogue IV (1965) 273-285. A lengthy defense of the concept's usefulness in social-scientific explanation is J. O. Wisdom, Situational Individualism and the Emergent Group Properties, with a comment by Robert Brown, in: Explanation in the Behavioural Sciences, ed. by Robert Borger and Frank Cioffi (Cambridge 1970) 271-311. 
continual generation of land-hungry arrivistes. They had a very clear sense of the interlocking conditions which I have mentioned as the essential preconditions of the Res Publica. For them, they were the causes of the city's greatness. Indeed, their talk of "greatness" is the closest the city fathers came to conceptualizing the idea I am setting forth here. We come across it most often when they speak about its fragility, when they remonstrate with the central government about how easily it can be damaged. The common argument went like this: the greatness of the city depends on the "train des marchandises", the flow of commerce, which the foreign merchants bring with them. The foreigners come because they know that the city's jurisdictional privileges shield them from things like the Spanish Inquisition or arbitrary extradition to face charges elsewhere. If anything were done to damage or contravene these privileges, it would frighten the merchants away, causing the collapse of the city's prosperity. This would end the city's ability to be of great service to the ruler ${ }^{15}$. No one said so at the time, at least out loud, but everyone knew that if this last misfortune befell, the chain of connecting disasters would come full circle: if the city could no longer be an important aid to the ruler, the main justification for many of its privileges would, in the ruler's eyes, have passed away, leaving the whole system vulnerable to another chain of degeneration. Thus, when the magistrates alleged a point of privilege in a dispute with the central government, the implications usually went far beyond the immediate specific issue. No doubt, they probably would have stood up for their jurisdictional and bureaucratic territory for its own sake anyway, but their consciousness of the interrelationship of privilege, urban prosperity and their own personal wealth regularly turned arguments over legal minutiae into a defense of the city's greatness. Moreover, the maintenance of and increase of that greatness was not just a matter of passive and defensive measures. In the 1560's, the town took on heavy indebtedness to build the Hansebuis, which was designed to attract business from the Baltic area. As with the new Bourse, the provision of a multi-lingual notarial system, and even the dedication of the new town hall's ground floor to commercial purposes, these actions show a continual active and positive concern to promote the conditions of the city's continued expansion.

If the Res I am describing emerged from the synergy of the legal commercial and political forces which made Antwerp a great and attractive city, what was the Publicum to which it was connected? The town council might function as its guardian much of the time - yet there were instances when the Res Publica's defense was undertaken in opposition to the city fathers. One such instance came in 1554, when the council attempted to enforce a new brewing monopoly which Gilbert van Schoonbeke had set up with its blessing and that of the central government. On the surface, the venture had the earmarks which distinguished my Res Publica - a collaboration between local and central jurisdictions to create an extraordinary commercial opportunity. But it was also a private monopoly which threatened to put the town's established brewers out of

${ }^{15}$ The most accessible document of this argument is the Request of February 1561/62, published in L. P. Gachard (ed.), Correspondance de Marguerite d'Autriche, Duchesse de Parme, avec Philippe II (Brussels 1867-1881) II, 196-120. 
business. Then, as now, Antwerpers took their beer very seriously; aside from the enormous physical inconvenience the new arrangements entailed, there were rumors about the safety of the new brew. The monopoly's introduction coincided unfortunately with orders to raise troops to aid the Emperor, who was busily fighting the French, and the town council's imposition of still higher beer taxes to support them. The tactless and arrogant manner in which the Pensionary handled the muster, particularly of the poorer citizens, led to riots, which the magistrates called on the armed guilds to suppress. Hugo Soly has given a wonderful description of how what he calls Antwerp's "middle class" - small merchants, guild masters and entrepreneurs - used the popular discontent as a wedge to get van Schoonbeke's project suppressed ${ }^{16}$. Basically, the infrastructure on which the town council depended to enforce its will and protect it from popular upheavals simply failed to function unless and until the monopoly was abandoned. That done, the military guilds were once again reliable, and the members of the city - which included the most conspicuously problematical elements of the infrastructure just mentioned - were willing to work with the magistrates to reimpose the unpopular extra taxes they had collaborated with the lower-class rioters in getting abolished. Soly's "middle class" cuts across the traditional structure of the city's four members: it includes some of the precinct masters, but not others; some of the guild masters, but not the wealthier ones. It was not formally a part of Antwerp's consent-granting mechanism, and its interests technically could be outvoted when push came to shove. But the events of 1554 showed clearly that it was an essential element of a consensus, whose support the city council needed in order to keep its position, and which could upset the whole of the city's political arrangement if its own concerns were trampled upon. Antwerp's working consensus had to respect not only the interests of the great traders and commercial bankers, but also those of a broader group of less well-to-do people. There might be a tendency to monopoly capitalism inherent in the position of the upper orders of urban society, but the maintenance of their social supremacy depended on their keeping the support of a group whose interests and aspirations demanded the suppression of that tendency. This balance of interests was itself an essential element in the broader balance of forces I have used to define the Res Publica; its constituency included Soly's "middle class" as well.

How specific can we be in defining this constituency? It is not just coterminous with the citizenry of Antwerp. For the most part it included the urban elite, at least when it was not pursuing monopoly capitalism. It included the foreign merchant colonies, whose interests were bound up with it and helped create it - even though they neither had nor sought official political representation. It included Soly's middle class. Did it include what people at the time called the volk, the menu peuple, who made up the majority of the city's population? On one level, I am tempted to say yes, since their livelihoods also depended on the city's continued greatness, and since, when their most basic needs were not met, their unrest could upset the basic social stability which

${ }^{16}$ Hugo Soly, Economische vernieuwing en sociale weerstand: de betekenis en aspiraties der Antwerpse middenklasse in den 16de eeuw, in: Tijdschrift voor Geschiedenis LXXXIII (1970) 520-535. 


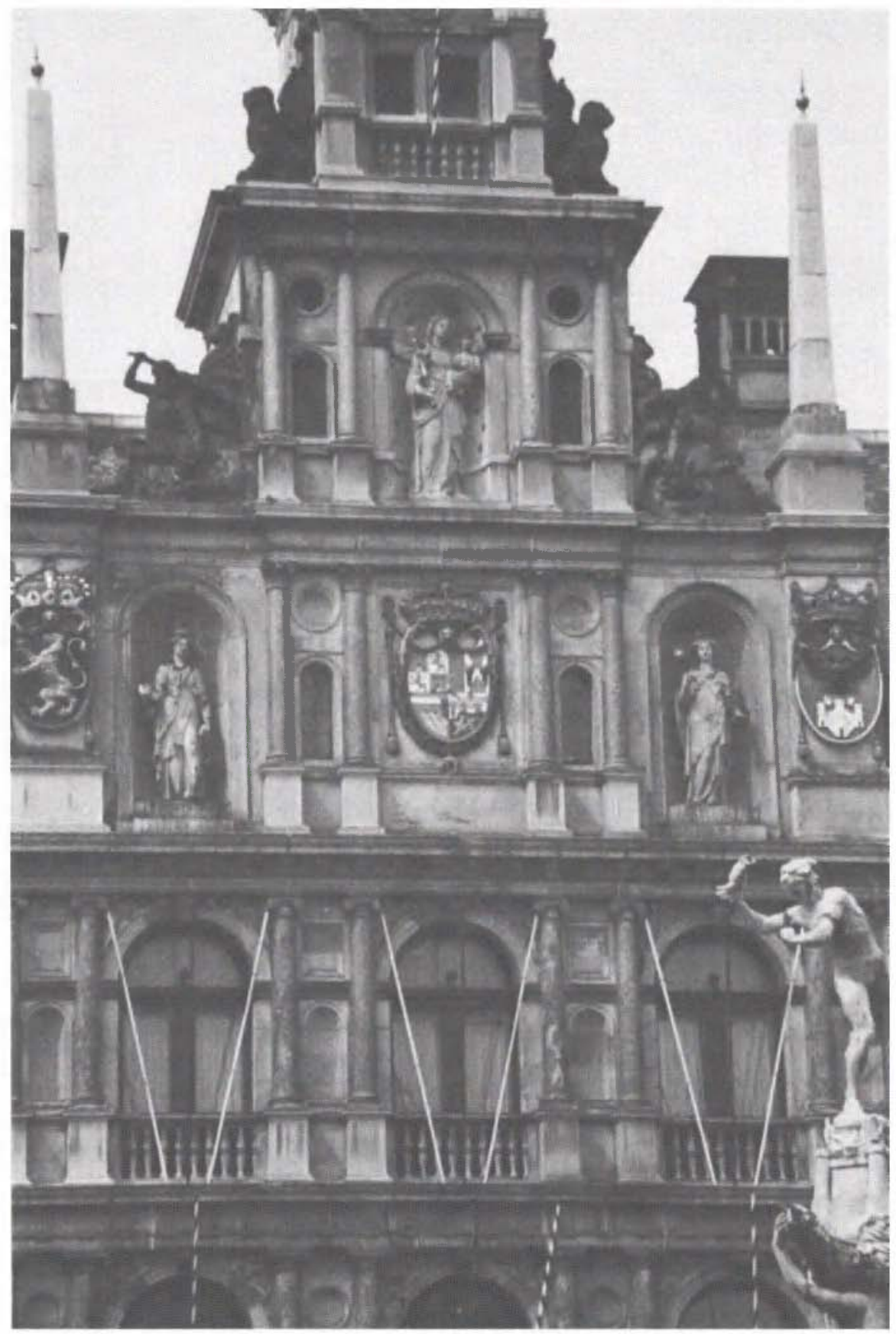

Antwerp's Town Ilall (detail) 
was necessary for the maintenance of the balance of the Res Publica. In another way, though, I would say this was more a matter of coexistence than inclusion. The state was not run to further their interests, but only to take them into account sufficiently to forestall upheaval. They were, to use a biological metaphor, its substrate. It may be that upward mobility was more possible in Antwerp than elsewhere - I would even say that hope for it was itself an important aspect of the Res Publicae. But participation in it, in any meaningful sense, came only with entry into that vague middle class we saw acting in 1554 .

Did the Res Publica's constituency include in some way the ruler or the central government? Certainly, they were the source of many of its underlying elements: the privileges, the trade concessions, and the larger polity within which Antwerp could grow. Likewise, the ruler was a major beneficiary of the city's greatness: the urban/monarchical collaboration which helped generate that greatness not only entailed access for the ruler to a major banking center, but an increased ability and willingness on the city's part to make large grants in the Estates ${ }^{17}$. The very operation of the Res Publica also served to keep the city relatively peaceful in a land well noted for the turbulence of its cities. But Charles' and Philip's empires were huge and interlocking amalgams of heterogenous states, polities and arrangements, of which Antwerp provided only one instance. The whole was intimately connected with it, but was not a part of it, and did not share its individual nature or qualities.

How can we summarize these qualities? Earlier, I characterized the Res Publica itself as an emergent property rather than a tangible thing. I think the most productive way to elaborate it is to compare it to a conventionally conceived republic, with regard to independence, polity, historicity, and liberty. When one speaks of a republic, the word has an almost magnetic attraction for the adjectives "free" and "independent". In the normal sense, Antwerp was not an independent city; the existence of the Res Publica, I have just emphasized, was specifically dependent on the continued good relations between the city, its ruler, and the other parts of that ruler's empire. And yet it is an independent quality, unique to the city of its generation, and embodying the distinct character of the people who participated in it. It was not a polity itself, but a condition of its being was a pattern of interaction among polities which was longstanding enough to be considered customary, and, therefore, possessed of a certain legal, if not institutional, force. Unlike the great city-republics of Italy, it was not itself historically venerable, though some of its generating conditions - particularly the legal privileges draw their particular force from their relative antiquity.

What of liberty? It is commonplace to say that in monarchies like that of which Antwerp was a part, there were liberties, but not liberty in anything like the sense Westerners understand it today. Certainly this is true of our city as a legal entity, of its institutions, of the rights of its inhabitants: what they had were the old proprietary lib-

${ }^{17}$ When we look closely at the negotiations in the Estates of Brabant, where we have taught ourselves to look for general opposition to government demands for grants, we actually find Antwerp and Antwerpers often leading the way to provide the ruler with money. On this see Wells, Antwerp, 166-168 and 224-226. 
erties. But in the Res Publica that emerged from the synergy of individually traditional institutions and forces, I would argue that there was a certain sense of liberty which was at once its essential characteristic and a cause of its ultimate dissolution. It was very limited: the individual elements out of which the Res Publica emerged would not by their very nature stand for attacks on themselves. But within this matrix of urban franchises and jurisdictional immunities and the relatively open atmosphere that Antwerp's polyglot merchant community both required and generated, there was a haven for a certain kind of adventurer. It was not just the specific liberties that drew people there from all over - it was also a general sense of opportunity, of freedom to try new ventures of all kinds. Tales of legendary commercial boldness were a part of its folklore $^{18}$, and the message was more than just a celebration of a chance to get rich though that was probably as far as most people thought about it. For those who pondered the social and cosmological implications of riches, though, it also carried with it the assumption of personal autonomy and independence in which the liberty of the Res Publica had its being. Antwerp was not just a place to make money, it was a place to go to hear about Utopia ${ }^{19}$. In Antwerp, with good fortune, people could adventure into the far reaches of the Baltic trade; take their chances on the new sugar plantations of Brazil; or just try to make it in the traditional vagaries and uncertainties of the English wool business. But spiritual adventures were also possible. With its grossly inadequate parish organization and its neighbourhoods teeming with visitors and unacquainted new residents, one could quietly ignore the hitherto obligatory details of traditional religion without attracting anyone's notice. In this alone lay a new freedom. To be sure, Antwerp's authorities vigorously persecuted heretics: but only when they attacked the traditional political order, or became so vocal that they endangered the city's jurisdictional immunity if they were left alone ${ }^{20}$. Non-revolutionary heretics those who could be discreet about their ideas and keep them out of politics, which were still very traditional - could live and venture inwardly without fears of inquiry or reprisal. Christophe Plantin offers us an epitome of the liberty of the Res Publica on all levels: he pioneered in evolving an industrial/capitalist organization in his printshop turned book-factory. But behind his extensive contacts with royal advisors and beside his church-related publishing ventures, he maintained his own special blend of heterodoxies, including close ties with Hendrik Niclaes and the Family of Love throughout the period before the revolt ${ }^{21}$.

${ }^{18}$ For the particularly egregious example of Gaspar Ducci, see Jan Goris, Etude sur les colonies marchandes meridonales (Portugais Espagnols Italiens) à Anvers de 1488 à 1587 (Louvain 1925) 375-381.

${ }^{19}$ Thomas More, Utopia, ed. by Edward Sturtz (New Haven 1964) II. Coming at the beginning of Antwerp's great efflorescence, More's fictional encounter embodies many telling elements: a chance meeting outside Our Lady's (i.e., just off the market place) with a city official (Giles) who brings two visitors to the city together to share tidings of newly discovered worlds and values.

${ }^{20}$ A. L E. Verbeyden, Le martyrologe protestant des Pays Bas du sud au XVIme siècle (Brussels 1960) 172-210, lists more executions for heresy in Antwerp before 1566 than anywhere else. But virtually all of these were Anabaptists, most of whom seem to have come from out of town.

${ }^{21}$ On Plantin's career and religion, the best study is Leon Voet, The Golden Compasses (Amsterdam 1969-1972). See particularly I, 21-24, 27-30, 55-57, 65-68. 
While I don't mean to say that the coming of Calvinism directly caused the end of the Res Publica, it certainly was involved in disrupting its underlying conditions. The harbinger of things to come was Philip Il's plan to erect a bishopric in Antwerp. To a Catholic ruler, Antwerp was an absurdly large city not to have a bishop - yet the city resisted the notion tooth and nail. Their reasons were explicit: a bishop would entail an inquisition, and that would frighten away the merchants and ruin the city's greatness. When pressed to show grounds for their fears, of course, the Antwerpers could not; they dared not say that the real thing that any bishopric would ruin, however benign its agents might try to be, was the general sense that no one was looking too closely at people's religious ideas. For a variety of reasons, the opposition to the bishopric was momentarily successful. However, by their resistance to the king's project the Antwerpers were giving what could be perceived as tacit encouragement to a group which worked hard at seeing tacit encouragement wherever it could. By maintaining the city's relatively open conditions, the city fathers maintained the conditions in which the Calvinists felt themselves at liberty to develop a group whose success, or attempted success in 1566-67, would lead to a dissolution of the conjuncture which generated my Res Publica. When Calvinism came out in the open during the Wonderjaar, in what was clearly perceived as a politically subversive and distuptive form, the town council was confronted with a set of choices, all of which involved an essential change. The magistrates' first choice was to do nothing, but that was clearly unacceptable: by then both ruler and Calvinists were demanding impossible things of the city which, if not granted, would lead to intolerable retributions or consequences. Briefly, at the beginning of July, 1566, at least a powerful faction of the magistrates decided that they would salvage most out of the situation of they introduced troops from the regent. When word got around, however, this provoked a reaction from within the city government: the precinct masters - whom we last saw in 1554 opposing the beer monopoly - forcibly took the keys of the city away from the burgomasters, in the midst of a popular demonstration that can only be seen as a near-riot. In terms of preserving the city's privileges, the next best thing to doing nothing was not to be to blame for anything, and it was with this in mind that the city fathers acceeded to Orange's designs to come take charge in Antwerp ${ }^{22}$. Above all, in the course of the crisis two essential aspects of the conjuncture underlying the Res Publica diverged: the preservation of the city's privileges, in which the town fathers ultimately did succeed, and the relative independence from outside observation and control which had previously gone with that. With this divergence, the evanescent liberty of which I have spoken dissolved back into a traditional collection of liberties. Paradoxically, this happened just when the cries of liberty in Antwerp were being heard openly for the first time. But they were the Calvinist cries for liberté de culte; they were signs not of any Res $P u$ blica Antwerpiae, but of a brave new Res Publica Cbristiana whose outlines were entirely alien.

${ }^{22}$ A detailed description of Antwerp's July crisis is in Wells, Antwerp, 414-38. 
In the discussion of an earlier paper, Prof. Blockmans asked what is perhaps the question of this entire conference: how does one get from monarchy to republic? I cannot presume to offer a full answer, but I think what I have described here might help point the way. Antwerp was not a republic in this period, nor was Brabant, nor was the Netherlands. But, like them, it did have a sense of commonwealth, which for all its insubstantiality was an essential aspect of it. The feeling of liberty I have described in my Res Publica was evanescent, fleeting, hardly even a self-conscious experience. But we can see it in people's behavior, their actions, their evolving expectations, their dreams. This state of mind arose from a state of things which conjoined in a monarchical state - indeed, which needed it to exist, but which, for a few historical moments, also transcended it. It would be several generations more before the scientific and philosophical breakthrough which solidified our modern ideas about liberty gave a name to what I think the Antwerpers felt. But their having felt it was one of many bits of accumulated experience which would give meaning to the later formulations. In 16th-century Antwerp, liberty was a momentary emergence in a situation where its explicit assertion would have been subversive and dangerous. A century later, it had emerged often enough and long enough in different situations that it had become plausible to regard its absence as the really outrageous anomaly. Spinoza and Locke were able to see so clearly and speak so meaningfully to others in part because the Antwerpers had first glimpsed through the glass darkly.

Let us, finally, return to the contemplation of the Town Hall with which I began this essay. Of the three pieces of evidence I first discussed, I fairly well dismissed two Guicciardini's description of the city government and van Stralen's mission to Frankfurt - as not giving us any real indication of local republicanism. The stadbuis I left to one side, noting only the ambiguity of its specifically political symbolism. I think we can now arrive at an understanding of what the building actually meant for the brief historical instant in which it and forces which generated it existed together. To do this, however, it is necessary to look beyond the arrangements of the façade to the other functions of the building. Earlier, I noted in passing that the first floor was dedicated to commercial occupancies. These were essential - the revenues from the first were earmarked to pay off the hefty rentes with which the buildings's construction was financed; without them, the project would have been impossible ${ }^{23}$. Upstairs, sitting on top of the commercial establishment, the city fathers tried to manage things so as to keep the flow of commerce going as freely as possible, maintaining whatever political ambiguities suited that purpose along the way. The iconographical equivocation of the façade was thus an essential part of the whole structure. Antwerp's city hall embodied

${ }^{23}$ On this see Floris Prims, De Ontwerpers van het Antwerpsch Stadhuis, in: Antwerpiensia III (1924) 87; also idem, Geschiedenis van Antwerpen, VIII, 1, 24. 
the interplay of the economic and political forces and arrangements which had made Antwerp flourish. If it was not an image of a theoretically acceptable polity, as we normally speak of polities, it was a true image of Antwerp's unspoken Res Publica ${ }^{\mathbf{2 4}}$.

${ }^{24}$ After this paper had been submitted for publication, I received a copy of Holm Bevers, Das Rathaus von Antwerpen (1561-1565): Architektur und Figurenprogramm (Hildesheim 1985). This contains a diskussion of the iconography of the façade, including changes that were made in the statuary after 1587 . 